\title{
Pages of History of the Nurota Oasis
}

\author{
T. U. Salimov, D. Bababekov
}

\begin{abstract}
This scientific article is called " Feature stories from the history of the Nurata oasis" and it uses the results of ethnographic field studies from 1999 to 2013, archival documents and scientific literature on this topic, as well as historical and ethnographic comparative information on the basis of dissertations and manuals. The article provides interesting information on the indigenous tribes of the Nurata oasis Oguz-Turkmen, their assimilation over many centuries and their transformation into Uzbek-Turkmen, as well as on other ethnic groups.
\end{abstract}

Keywords: Nurata, ethnic history, historiography, ethnography, ethnic composition, tribe, Oguz, Oguz-Turkmen, nomadic and semi-nomadic people, trade, lifestyle.

\section{INTRODUCTION.}

Based on the latest archaeological, written and Internet data, Nurota's stages of development can be divided into the following periods:

- Early Paleolithic (1 800,000 years) in the Karatau-Nurata area: human beings were engaged in harvesting and hunting with stone tools;

- Middle Paleolithic (100-40 millennia) stone tools from reefs from Ijond and Uchtut monuments to the south of the Zarafshan oasis - the Nurata Mountains;

- Mesolithic (VII millennium BC) Kyzylkum region: human development of these territories, emergence of domestic livestock;

- The Neolithic-Eneolithic Period (VI-III millennium BC) The emergence and rise of the mining industry of Nurata-Farish steppe;

- Transition from open pit mining to mining. The emergence of animal husbandry, irrigated agriculture, the emergence of gardens and nuts along the mountain valleys;

- The Copper Period (III-II millennium BC) The beginning of ore melting in the Karatag region. Increase tree felling on mountain slopes;

- Antiquity VI-III centuries from the Nurata Mountains: extraction of copper, iron and turquoise, the remnants of workshops, archaeologists finding slag; increasing migration from the Khorezm and Samarkand regions, development of mountain and piedmont oases, expansion of felling of juniper and other trees for fuel and ore mining;

- From the beginning of the XIX century on the mountains of Nurata various kinds of marble, iron, and light-colored. From this period the felling of trees will increase in the upper part of the mountain;

Revised Version Manuscript Received on 16 September, 2019.

* Correspondence Author

*T.U.Salimov, Professor of the History Faculty of the National University of Uzbekistan, Tashkent, Uzbekistan

**D.Bababekov, Teacher of the Faculty of History, National University of Uzbekistan Tashkent, Uzbekistan
Young scientist AN Togaev, who researched the ethnography of Nurata as a topic of his thesis, divides the population into the following strata, depending on the time and lifestyle of the oasis:

- The first representatives of the settled population were Uzbeks and Tajiks, Turki-speaking, Sayid, Eshon, and khosh groups.

- Turkmens of the Oguz tribes, who gradually migrated in the Nurata mountain oasis since the Middle Ages (X century). Their farm gradually evolved from half-breeding livestock into livestock farming.

- The tribes of the Uzbek tribes who came to Nurata oasis since the 16th century: mangitites, naymen, lizards, slaves, faces and others. This population also has been engaged in animal husbandry for a long time ${ }^{1}$.[1,p.28.]

The people of the region have long been linked with nomadic Kazakhs and Karakalpak tribes living in the Kyzylkum, which is located north of the Nurata Mountains.

In scientific literature the process of formation of the first states in the country It is marked by the IX-VII centuries. The pre-Achaemenid state associations are as follows:

1. Aryoshayona is an association of genius (ancient region conception) of ancient regions.

2. Aryonam Vaijo is the "Greater Khorezm" or the Lower Khorezm State in the Amu Darya, with its headquarters in Aryoshayon or its center in Aria and Margiana.

3. Ancient Bactrian state. It includes northern Afghanistan, South Tajikistan, and the present Surkhandarya region. Sogdiana was originally part of ancient Bactria. Sogdiana is now Samarkand, Kashkadarya, Bukhara and Navoi regions.

The "Gava space" mentioned in "Avesto" in the book "Yasht" is probably the oldest province of Sogdiana, Sogdiana. In addition to internal social causes, the acceleration of desert settlers and the aggressive policy of the Midwest were also fueled by the emergence of state associations. [2, p.16.]

During this period, the Nurata oasis belonged to Sogd, and its grassland inhabitants were engaged in irrigated agriculture, using river water and springs. The herders also engaged in additional livestock. From early spring until late autumn, sheep, cattle, and horses were grazed on the slopes and mountain pastures near the village.

Camels were grazed in Kyzylkum, near Nurata. In the foothills and gorges of Nurata, pottery, blacksmithing, and other handicrafts sectors developed.

Nurata's underground gold, in antiquity, has attracted neighboring countries, particularly the Chinese. According to the historian Herodotus, the Sak-Massagets living in our country made their own weaponry of iron and decorated it with copper and gold.[3,p.36.] The population has also developed ceramics, jewelry, textile and

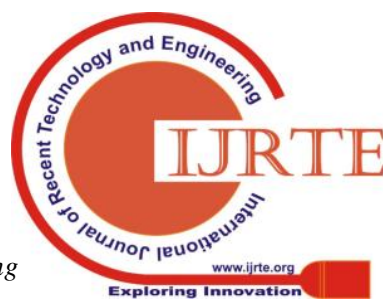


construction. Gold mining in Koratog, Mangyshlak, Nurata, Kyzylkum, Zarafshan, Sogd, Chatkal, Fergana was known even before the arrival of the Turks (6th century BC). According to Azamat Ziyayev's article "Karakhanids," gold, copper, lead, mercury and marble are known to work in the mountains of Nurata. [4, p. 3.]

It is clear that among the nations who revolted against the Iranian sultan's rule in the sixth century for freedom and freedom, the Nuratau ancestors and Sogdians also participated. The legend of the Saka Shepherd, the Saks, is of particular importance in this regard. Greek historian Polien (2nd century BC) cited the Saks story in his work "Military Tricks". The Saxe tribes lived in the area adjacent to the Nurata Mountains of Kyzylkum with the Sogdians. A part of the Persian army led the desert into a waterless desert and was overthrown by Ranosbat, commander of the Shirak Dari I However, this death was not a defeat for Shirak because of the fate of his motherland and country. Despite the fact that the shield itself was destroyed, it would save its countrymen from the great disaster, especially the Sogdians in Nurata. The Iranian emigrants have ruled our country for more than 200 years. [5, pp. 64-65.]

In Nurota, in our country There are many legends and myths related to the name of Alexander the Great, which he conquered from 329-327. In the village of Zulkarnain, the legendary tomb of Nurata, who founded the city in the village, and drilled 360 maize in the oasis, has been passed on for centuries from mouth to mouth, and now from one work to another. In general, this is not surprising, as all people's good wishes and dreams are associated with great people. Shortly after Alexander's death, Sogd Salavkie, who was a member of the Nurata, was then part of the Greco-Bactrian Kingdom.

Greek historians record the construction of 75 cities in Central Asia during the reign of Salavka I and Antioch. During this time, the economy, culture and culture were on the rise. Archaeological and ethnographic research in Nurata, Aktog, Korogat and the oasis between them in the 70-80s of the 20th century has resulted in ancient settlements, fortifications and ruins of large cities and towns. During our visit in April and June 2013 (Prof. Sulaymanov, Associate Professor A. Kabirov, T. Salimov), we observed the fortress of Nur, Gazgantepa, Dehibaland, Pashshot Castle, Bushang Castle, in the economic center of Sogdiana. We are convinced that it is necessary to study archeological monuments. [6.]

Among the ceramic items found in the fortress of Nur, the museum of local lore of Nurata, the mausoleums of Aktepa, Pashshot are antique. There are fragments of earthenware vessels dating back to the fourth century BC. These fortresses and fortifications were undoubtedly designed to protect the northern Sughd region, as well as the Nurata oasis and surrounding areas from enemy attacks. At the end of the Greco-Bactrian kingdom (250-130 BC) the Yueji tribes attacked from the northeast. The cities like Alexander Escata and Alexander the Margiana will be destroyed. It is likely that Nurata in northern Sughd was not ignored.[ [7, pp. 160-166.]

In the III-II BC centuries in Sogdiana the fine arts, architecture, jewelry and other kinds of applied arts were highly developed. In this regard, pictures of the various rock scenery and landscape paintings of the rivers flowing between Nurata Ogt and Karakata are worth noting.

They were plastered on the slippery surfaces of the fortresses and their ancestors: men with bows, swords, daggers, hats, mountain goats, dragons, gazelles, gazelles, pigs, and trained cheetahs - hunting tigers, wolves, foxes, turkeys, saigas. carvings, horses, camels, donkeys, cattle, oxen, animals, carts, lions and tigers, with a very delicate taste and skill. In this respect, pictures of Sarmishsay, Bironsoy, Qorachorvaksay, Karaungursay, Dolanasay and Kuksaroy flowing through the Karatau area are worth noting. The oldest of these rock images was It belongs to the II millennium. Among the rock paintings are the Mt. It is also common in the 4th and 3rd centuries.

As to the religious beliefs of the Sogdians in Nurata and adjacent areas, their ancestors first worshiped the forces of nature, high rocks, giant trees, springs, and later Zoroastrianism. For natural Nurata Sogdians, the belief in springs, water, earth and the sun deserves special attention.

In April 2013 we visited Zulkarnain village in Nurata district. On one side of the village a marble-walled room has 2 tombs in it, no less than 10 meters in length. A white cloth is laid over the grave. According to information, one of the graves belonged to Zulkarnain and the other to his mother. In our view, this symbolic tomb is empty. [8.]

While Alexander was standing on the banks of the Syrdarya, Marakand was occupied by the rebels led by Spitamen. Sogdians ambush along the Politimet (Zarafshan) River, killing 2,000 soldiers. Alexander returned with the main army and pursued the rebels led by Spitamen to the desert. It is believed that Alexander, during this march, rested in a small valley surrounded by present-day Zulkarnain and then returned. The population probably named the village. It is worth noting that in the Ferghana region there are also Zulkarnayn Cemetery, Jarkurgan of Surkhandarya, and bridge dams named after Iskender Zulkarnayn in Panjikent district of Tajikistan. Except that Alexander did not invade Ferghana, his troops passed through the next two places and undoubtedly laid the groundwork for naming it.[9, p.156.]

In general, in the antiquity of the peoples of Central Asia, including Sogdiana in Nurata, there was a period of positive influence of the Greco-Hellenic material and spiritual culture on our country.

It is well-known that the state of Kango occupies a special place in the history of Central Asian nations. According to the academic ethnographer Karim Shoniyozov, m.a. The state of Kang, which was formed at the beginning of the III century, lived till the beginning of the II century AD and subjugated Khorezm between Amudarya and Syrdarya.[10, p.154] According to academic A. Askarov, the population of Kang is represented by tribes and ethnic groups, who speak both Turkish and Sogdian languages. [11, p.280] At that time the Nurata oasis was under the state's control. Sogdiana, as well as the cities and villages of the Nurata oasis, developed ceramics, blacksmithing, mining, and rock climbing. Nurata's peasants produced wheat, barley, peas, melons, watermelons, grapes, apples, apricots, pears, quince, peaches, mulberries, and other fruits. In the desert, camels, sheep, goats, mountain and alpine meadows were grazed on cattle, horses, and sheep.

During this period both internal and external trade developed in the northern Sughd region, in

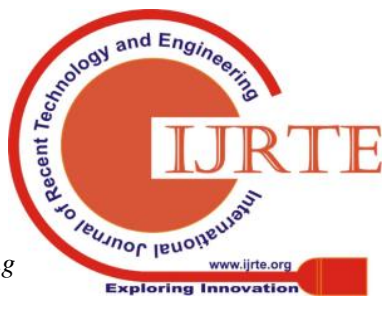


particular, in Nurata's small villages.

As is well known, m.a. From the II century the Silk Road was formed. The Great Silk Road originated in Xiang, the ancient capital of China, and came to Dunhuang via Lanjou. Here he parted, with the south-west branch coming from the Takamakon Desert to Khotan, thence to Yorkent, through the gorges of the Pamir Mountains to the Vohandarya Valley, then to the ancient city of Bactria, the ancient city of Bari.

The north-west branch of the Silk Road runs from Dunhuang via Bami, Kucha and Turfan to the Tarim Valley to Kashgar. From there it passes through Tashkurgan to Uzgen, Osh, Kuva, Axikent, Pop, through Asht to Khujand, Zaamin, Jizzakh, and then to Samarkand-Bukhara, Chorjuy, Merv. From Merv, the Silk Road crosses cities and countries on Iran, Mesopotamia, the Caucasus, Asia Minor, and the Mediterranean, reaching a final destination of $12,000 \mathrm{~km}$ in Egypt.

In the Silk Road caravan trade there were many Sogdian traders, especially those from the Nurata sights, caravans and guards. It is worth noting that after the Great Silk Road entered the northern Sughd region, it crossed the villages of Nurata oasis through Samarkand, Ishtikhan, Korsafar and Koshrabad. The Silk Road played a major role in the political life, economic, cultural and commercial life of the northern Sogdians, as well as the Nuratau Sogdians. Thanks to this way the people of Sogdiana widely used the Eastern and Western world and their economic achievements and inventions.[12, p.27]

During the reign of Kushan the control of caravan routes through Central Asia to the West was in Sogdians. The Sogdians built their fortresses and settlements in eastern Turkestan, Ettsuv, Altai, and Enasoy, in the Chinese province of Shanxi, in the city of Dunhuang. According to sources, in the city of Dunhuang, China in the III-IV centuries there lived thousands of Sogdians. During the Kushan period, the movement of caravans on the Great Silk Road became active, and Sogdian, Nurataan caravans and traders crossed the foothills, sand dunes, the Ferghana Valley, Ettisu, Ili rivers, and through Eastern Turkestan to China and South Siberia (Central Asia). From the west to the east, the Sogdian caravan and merchants arrived in Morocco, the capital of Sogd, in search of their homeland. The roads in Morocco, Ishtikhan, Mitan, Oktepa, Korsafar and Kushrabot make them great markets in Nurata and the surrounding villages, where they traded goods and traded goods to locals and Kyzylkum.[13,p.170]

From the east, caravans and traders enter and carry out trades from Jizzakh to Nurota and Kyzylkum villages, through Osmonsay, Ilonsoy, Forish, Uhum, Big Ej, Small Ej, Temirkovuk, on the north and northeast slopes of Nurata mountain.

Thus, the antiquity of the people of Central Asia, Uzbekistan, Sogdiana and Nurata is over, and the next stage of the history of society goes back to the Middle Ages.

The Khionites, the Kidars, and the Eftalians ruled from 353-565. In the history of Nurata oasis, important dates and events related to the period of the Khionites and the Kidarians were not preserved. However, the ethnonymes associated with the Ephalians still exist in the oasis. The second part of the village of Karabdal, which is part of the Farish district, is found in the area of Abdal-Weekal in the form of "hyal" and "abtal" to the Anatolian region of Asia Minor. Archaeological investigations and written sources of settling of Eftal tribes in our country intensified in the V-VI centuries. When the Byzantine Emperor Justin II (568-569) asked the Sogdian ambassador about the Euphrates, the ambassador would answer them as tribes inhabiting the area. [14,p.137-139]

During the Eftalids' reign in the foothills there was a widespread use of water for the hills. As there were no rivers in Nurata and the surrounding areas, they built underwater structures - dumps and irrigated crops in areas where there was no access to the pool water.

It is noteworthy that the marshes between the mountains of Nurata are one of the major centers for the cultivation of corn. In the newly developed land along with fortified noblemen peasants, built on high basements, with high and thick raw bricks, low-walled fortifications surrounded by low-walled houses of working neighbors.

For centuries, the fortress of Nur Kala was one of Sogdiana's settlements and it was a military strategic shopping center. The light was on the border with nomadic tribal herds north and was always under the threat of enemy attacks. The people of the Light served as a shield against the invaders who had invaded our country from the north-east, north and north-west for centuries. The City of Light and the Fountain of Light around it are $500 \times 500 \mathrm{~m}$. In the ancient times the gateway was entered by one gate. It was called "The Gateway". The road leading from it is in the middle of Pirosta, the northern defensive wall. The archaeologist, orientalist, historian H.Muhamedov provides information on the Pirosta Wall in his work "Ancient Defense Walls" (1961-1973). "The Pirosta Wall existed from the 3 rd century BC to the X century AD. Its length was 20-21 km." Academician Ya.Gulyamov in his article "Central Asian Ethnology and Archeology" wrote an ancient Pirosta wall.[15, p.135] The rectangular shape of the city, and the people of the city defended themselves in any case. Archaeologist OM Rostovtsev, after his archaeological research in 1974, developed a plan for the Pirosta Defense Wall. R.Ahmedov of Nurota states that the fortress and city of Nur had gates called "Darvozayi Pirosta", "Darvozayi Rabot" and "Darvozayi Shodi". Hungarian tourist A. Vamberi wrote in his book "History of Bukhara or Movaraunnahr" that "the gates of the fortress of Nur" were opened.[16,p.22]

Originally the nomadic eftals continued their traditional nomadic farms, grazing on pastures in the Kyzylkum Desert, some of which were adjacent to the slopes of Nurata, Aktog, and Korogog. Later, some of them come to the foothills and springs in the Nurata and Aktog mountains, setting up winters and moving to semi-pasture and grassland. Over the centuries, the Eftalians have mixed with the local Sogdians.

Archaeologist scientist A. Kabirov studied and painted thousands of rock paintings on the smooth surfaces of the Koksarai, Bironsoy, Qoracharvaksoy, Big Ege, especially Sarmishsay gorge between 1966 and 1978. On the rocky surface, there are paintings of people, various weapons, various wild animals. There are pictures of domestic sheep, goats, donkeys, donkeys, camels riding on horses, horse riders and other animals of different times. Some of these paintings were made during the period of the Khionites, the Kidarians, and the Eftalians.[17,p.50]

Craft and commerce flourished during the Eithal period. The Ethiopians have relied on military power in their policies and have taken control of the Silk Road. At that time in Sogd

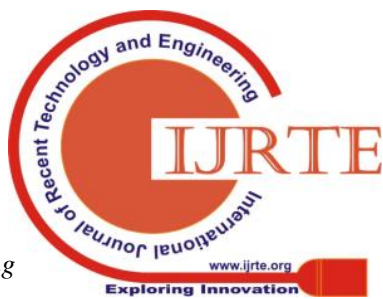


and Nurata traded gold, silver, Badakhshan mud, Kyzylkum turquoise, colored glass and glassware, cotton, leather, breeding horses, raisins, peanuts and other fruits.

There were different forms of religious belief during the Eftalids. Archaeological and written sources indicate that Zoroastrianism was widespread in Sogd, especially in Nurata oasis. When it comes to the language of the population, the herders speak Turkish and it is becoming more and more common. But Sogdian and Nurata's native population spoke Sogdian. The Sogdian language as an international language has been extended to Ettsuv, Fergana, and East Turkestan. Although the Turks defeated the Ethiopians in 563-567 and annexed the country to the Turkish kaganate, they remained in Seattle and maintained local government. The largest of them was Sogdiana and had the title of its governor.

The center of Sogdiana was Samarkand. The northern Sughd also includes the skirts of Nurata, Aktog, Korogat and Kyzylkum. People living in these areas have a strong relationship with Soghd. Archaeological and written sources indicate that the Sughd rulers established diplomatic relations with Central Asia and foreign countries. For example, wall paintings from Afrosiab depict the arrival of Sughd Governor Varhuman to the ambassadors from Chaganyan, Chach and China.[18,p.237]

During the visit of Professor R. H Suleimanov and Associate Professor A. Kabirov on June 15-16, 2013, a stamp of the Governor of Sughd Varhuman was found on the top of the ball found by schoolteachers T. Ergashev and N. Ergashev in the village of Oktepa in Avazsoy. This unique finding is evidence that the mountains of Nurata and its surroundings belong to the northern Sughd region. The northern and northern parts of Soghd and its unique surroundings are densely populated and crowded around Nurata. This is also evidenced by the abundance of artifacts found throughout the Nurata district in the pre-Sintab area.[19,p.2]

The Sogdians and Nurataans were extremely influential in crafts, trade, agriculture and gardening, especially in viticulture. Sogd lands irrigated by such large rivers as Darghom, Nakhrifay (Narpay), Harkon and Bulungur, which received water from Zarafshan, were very fertile. Apart from wheat, rice and rice were planted in this irrigated area. Not only the Sogdians, but also the entire steppe, adjacent to the Nurata oasis, wore cotton wool and cloth. Great drink made from sweet-sugar, juice of Sogd and Nurata. The name of the "Golden Peach of Samarkand" has gone far and wide. Apples, pears, dried black and yellow raisins, leaves, and peaches were known throughout the East in the villages of Nurata, Aktog and Korogog.

During this period cattle breeding was developed in Sogd, Nurata and adjoining oases in the foothills of the Kyzylkum. In the oasis and adjoining steppes, horses, mules, donkeys and breeded camels were grazed along with small and large horned cattle. Sogd and Nurota's tombs were very popular. According to written sources, bumpy horses were transported from Sogd and Nurata to neighboring countries, including China. In this period, as in the past, the demand for Fergana, Sogd - Nurata horses was in great demand.

According to local legend, the famous "Water Storms" lived on Fozilmon Lake just above Sintobsoy.[20,p.3] This is a legend, but there is no doubt that there is a historical truth behind it. At Nurata's pastures, the herds of Aktog and Korogat have been developing at a very high rate from the earliest times. Images of rocky horses, slaves and horse riders in these areas are among From the I millennium BC to the VII century are also found.

During the Turkic Kaganate, Central Asia, especially in Sogd, experienced relative peace. At that time Nurata, a remote area of Sogd, collected water from streams in and around the lake in "lock pools" and used them for irrigation of arable lands. Farmers of the area planted and cultivated several varieties of grapes. In Nurata, people lived in densely populated rivers, such as Sintob, drinking water from the ears of the streams, and watering their homesteads. According to the press, this tradition has been and continues to date.

Many pieces of material from the ruins of Nurata oasis have been found in pottery, pottery and copper, and are now in the museum of local history. In this regard, the Bogang Castle and the items found there are remarkable.

In the book "Gazgannoma" about the fortress of Gazgan, R.Asatov, a talented creative teacher, writes: "In one of his works, the famous Uzbek historian Ya.Gulyamov wrote about the fortresses around the light, and called them" fortresses ".[21,p.134]

According to our grandfathers, R. Assatov wrote that these fortresses were built to warn the people against the invasion of the enemy. Firewood, horns, and fires were gathered to the top of the village to warn the people of the enemy coming to your bush. When the people saw this, they took steps to hide from their enemies.[22,p.27]

I have heard that these barrows, especially the Bushang and Ghazgan fortresses, were built and I saw that there was a mouth from the top of the fortress built on the spring from Gazgan. There was a big tax collector nearby.

The entrance path is in the form of a staircase, the top is covered with rods and the soil is drawn. It was found that these corridors were 40 meters long and more, at the end of the staircase, near the fountain, to the pillars, shelves and small platforms. Foods and candles are on the shelves. It is also interesting to note that every twelve meters there are transverse holes in the air. They are adapted to air circulation, and we can see that several family members can survive, depending on the area of the area. Burials, jars, pottery, and stone are still visible around the burial ground.

There is a cave in the south-west of the fortress, which is called the cave of the Saint's Father. They had gone to the cave, away from the pleasure of the world, from injustice and injustice. Our mothers had a wink and lit a black light here. According to R. Assatov, the Bushang castle is one of the oldest fortresses in Nurata, and it is not accidentally said in the national language, "Qasri orifon King Boshang!" A large number of enemy occupations were killed, and the survivors fled to Ghazghan and saved their lives in Bo'i Busan. This fortress is surrounded by countless foundations, glass, ceramic fractures, fragments of porcelain, northeast side and cemetery.[23,p.43]

Pashshot Castle is one of the oldest archaeological sites in Nurata. It consisted of rabat surrounded by fortresses, citadel and walls. A local collective farm owner, Mansur Jumaev, found a valuable ring in 1994 in the vicinity of the village. The chairman assumed that there was a treasure, and he worked with the collective farmers to dig. In the ditches on the Kurgan road there were ceramic pipes which were connected to each other and turned north. The brick was made by the brigade of Kakhramon Ramazonov. 
Apparently, the fortress was built on a well-timed spring, and the excess water from the spring was pumped out through ceramic pipes. Even today, water is coming out of the village and is joined by a stream of water from above. We have seen this scene many times during our trip to Nurata. Pashshot is an ancient fortress with many stories about it.

According to legend, Pashshot was once a fortified stronghold. The fortress walls extend from Nur to Kushat. As the picture shows, the kid jumps from the roof to the roof and goes up to Koshat. The sound of the fountain fountain was heard before the song.

It is said that the story "Sharsharai Pashshot" and "Gulchai Koshat" came into being. According to R. Asatov's brochure, the governor of Pashshot Castle was a woman who was very brave. The enemy commander (the Arab and the Mongols), who took the Light fortress without war, sent a letter to the governor of Pashshot asking him to submit and be welcomed. The governor of Pashto rejected the offer, saying that as long as my body was alive, he defended the fortress and defied it. An angry enemy commander shoots at the fort with his fighters shooting at Pashshot. The castle is left in the flame of fire. But no one will come out of the fortress with a white flag. The army chief poured fire on the fortress one night. Inside, everything is dying out, and even people are jolted and burned. Smells and smoke all around. In the castle, the voices are silenced. Then the commander stopped the attack by saying "low shud" - "quenched, quieter". The castle is a heap of cults. Since then, the castle has been called the "low dew" Pashshot - so far. This fortress may well have been named after it.

The spring water here is a large ditch, and the pool is used as a bandwidth for the crops. From ancient times the water of Koriz and Sumbulbulak was sent to the herders by pipes. Watermelons and melons and gourds of Gazan farmers have been watered by these waters since ancient times. Population of melon - watermelon, vegetables.

When we visited Pashshot, Gazgantepa, Dehbaland, Castle of Light and Fort in our trip in April and June 2013, these monuments were used for various periods of our history, even from the ancient Palaeolithic era, with pieces of lightning. In the III-I, IV-IV centuries and beyond, we found various pieces of ceramics, brass, and whole humus and jars. Based on the aforementioned data, it can be said that people lived in and around Nurata for 120-100 thousand years.[24,p.3]

It is known that at the beginning of the eighth century AD, the Sultanate of Arabia occupied Soghd. At present, residents of Sogd and Nurata oasis Used the Sogdian writing of the III-II centuries. According to the Arabic geographer Magdisi, the Sogdian language was preserved in villages around Bukhara at the end of the 10th century. We can conclude that Sogdians speak Turkic and Sogdian languages.[25,p.272]

Prior to the Arab invasion, Zoroastrianism was the main religion, with fire, water, land and air being the four sacred elements.

According to this belief, even suppressing the extinguished ashes of fire is forbidden, water is respected, and dirty things are forbidden to be put into the water. The dead are symbols of evil and are forbidden to bury, bury, and pollute the air. The body of the deceased had not been lit for several days and no food was cooked. The corpses were left on rocky hills, with high walls surrounded by specially constructed walls.

Professor A. Hidoyatov told about his scientific tours in India at the invitation of his Indian counterparts on a hill surrounded by Zoroastrian graves at night. As soon as the corpse is laid, the white ravens from the trees around the hill will be thrown to him. In the distant past, as we have done in the past, the bones have been dried up in the sun, and they have been collected by special staff and placed in coffins and coffins. The Persian Zoroastrians in India emigrated from Iran to India to retain their religion during the Arab invasion and still maintain ceasefire. The parts of Avesto that have come down to us have been kept by the Indian Zoroastrians.

After the Caliphate, it was not easy for the people of Movarounnahr to embrace new religion, language and spiritual values. Previous religions, writings, rituals and rituals of the population are prohibited. Those who do not accept Islam are subject to the Jizyah tax. They also give 2 dirhams to those who attend the mosque. This is also reported in the book "History of Bukhara" by Muhammad Narshahi. Popular uprisings cover the whole of Movarounnahr and Sogdiana region in particular. The country will be one of the most rebellious territories during the rule of the Khilafah.[26,p.53]

Since the establishment of the Samanids rule in the country, from the 9th-10th centuries there has been development and improvement in all spheres of the national economy. New dams, reservoirs will be built and new lands will be developed in the northern Sughd and its constituent parts of the Nurata oasis.[27,p.107]

At the same time, the Old Forish, near the present Yangikishlak, was built and commissioned by the Khanbandi Reservoir. Fountain water from Nurata, Aktog, and Koratag slopes will be created by the construction of lock pools in the streams, and the opportunities for water supply to the fields will be expanded. On the slopes of slopes new corridors will be constructed. The rain-fed crop extends: wheat, barley, flax, mash, peas, melons and watermelons grow.

Horticulture is well developed in the watery villages of the region. In the orchards, fruits such as apples, pomegranates, pears, peaches, cherries and grapes bear fruit. In the city of Nurata a number of branches of textile, ceramics, carpet weaving and crafts are developing. During the Samanids, livestock was also developed, and its karakul sheep breeding was established.

The Oguz is one of the ancient Turkic tribes in Central Asia and South Kazakhstan. Their first location was in northeastern Mongolia. According to the well-known embassy scholar Kazakboy Makhmudov, the Seljuk people belong to the Oguz tribe.

According to the Arabic geographer Ibn Khawqal (X century), about a thousand Turks who converted to Islam emigrated from the east to the area between Farob, Kenjit and Shash, southwest of present-day Shymkent. Oguz - son - tribe - means seeds, and "own" is a suffix.

The alliance of the Oguz was formed at the end of the ninth and early 10th centuries along the Aral and Caspian seas. The state of the Oguz, whose capital was Yangikent on the slopes of the Syrdarya, was formed in the tenth century. However, they were soon defeated by the Kipchaks, and some of them moved west to the Russian steppes. The rest of the Oguz people, led by the Seljuks, settled in present-day Turkmenistan, north of the Aral Sea. According to written sources, the part of the Oghuzs who converted to Islam and mixed with the locals were called Turkmen. According to

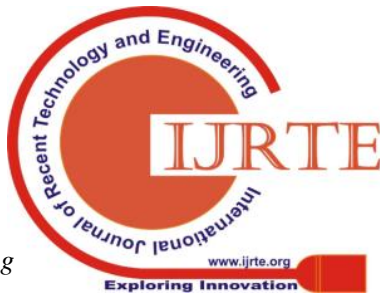


Mahmud Kashgari (11th century), Ibn al-Asir (11th century), Rashididdin (13th and 14th centuries), Abulgazihan (17th century), Oguz consisted of 22 or 24 tribes. They are chow, scarlet, emelli, cigars, prints, samir, brunette, life, coyote, tuturga and others

Saljukbek was the founder of the Seljuk dynasty, the downstream of the Syrdarya river, the Oguz state, which was formed in the north of the Aral Sea. According to Ibn al-Asir, he lived long and died at the age of 107.[28,p.76]

The Seljukbek was originally part of the Yangikent rainforest. But he could not reconcile with them and approached the governor of Jand on the lower left bank of Syrdarya. When the governor of Jand disagreed with Shahmalik, he moved to the mountains of Nurata. The Samanid rulers allow the Oguz people to live in the Nurata steppe pastures. Some of the Nurata's mouths remain, while the rest cross the Amudarya and settle in what is now Turkmenistan. The mouth of the mouth lived in the Zarafshan Valley and the foothills of Nurata. The first groups of these settled in VIII-IX centuries. During the 10th century, their number had increased considerably. Although most of the Oguz Seljuk people migrated to Khorasan in the first quarter of the 11th century, some of them remained in the Nuratai suburbs and mixed with the Uzbek tribes.[29,p.89]

After the end of the Samanids state in 999, Nurata was taken over by the Karakhanids. The Oguzs, who settled in Khurasan, began the war against Masud al-Ghaznavi in 1038 and formed the Seljuk State. The first capital of this country was Ray in Iran. The Sultan of the Seljuks, Sultan Sanjar, defeated the Karakhanids and made them an independent state. However, the Karakhaians, who invaded the country from the northeast in 1137 and 1141, defeated a combined army of Karakhanids and Seljuks in the Battle of Qatwan, and the rise of the Khorezmian state forced the Seljuks to retreat to Asia Minor.

During the suppression of the popular uprising against Khorezmshah Sultan Muhammad in 1212 in Samarkand, the last Karakhanid ruler Usman was executed. During the Genghis Khan's march against Khorezm, in the winter of 1220, the fortress of Nur was captured by the Mongols without a fight. In addition to paying taxes to the Mongols, the people of Nur supplied agricultural products, equipment, supplies, and fodder.

In H. Wamberi's book "The History of Bukhara or Movaraunnahr": "With Genghis Khan's son Tulikhan ... From Utar to Bukhara we only know that his first stop was the city of Sartak (Zarnuk). This city is located north of Bukhara. They will take this city without a fight. The Mongols called Sartak (Zarnuk) the "Happy Happiness" (the city of happiness). The second city conquered by Genghis Khan was Bukhara.[30,p.21-22]

He came here with the help of the Turkmen bandits, which for a long time was called the "Khan's Path". Long staircases were made from trees in the woods around Nur, under the leadership of either Muslim or Turkish, Tahir Bahodir to attack the castle. The stairs were mounted on horseback or by hand and placed on the city walls. The gates were partially closed due to the support of Sultan Muhammad Khorezm. Tahir Bahodir told them, "There is a really strong Mongolian Khan who will stay for a few days if the city's population does not resist." And the gates of the city of light were opened. According to the order, they leave the town with the necessary tools and animals for agriculture.

Then the Mongols entered the city and plundered their houses, not killing people. Negotiators who went to Genghis Khan on behalf of the people were welcomed. When asked, "How much did you pay?" He then ordered the money to be brought to the military court, and sent the delegation back.

Genghis traveled from Nur to Bukhara. At the beginning of the month of Muharram 617 (1220), he set up his camp near the walls of Bukhara.

In 1370 our great ancestor Amir Temur put an end to the Mongol rule for almost a century and a half. During his activity Timur pays great attention to the prosperity of the country. It opens the way to the development of agriculture, crafts, livestock and trade in the country. Amir Temur visited the places of pilgrimage in Samarkand region before the military campaigns.[31,p.430]

In particular, the chroniclers of the Amir Temur epoch note that the lord was in a number of settlements in present-day Navoi region. During Amir Temur's time, many cultures, gold, copper, marble, etc. were excavated from Nurata, Aktog, and Koratai. Sogd and its towns and villages flourished.

During his travels, Amir Temur spent a week in the Raboti Malik Palace. During this time he visited the holy places around. Sources say that our grandfather drank from the water of the spring of light and visited the grave of the scholar Hasan Nuri.

Ubaydulla Uvatov, a doctor of historical sciences, narrated from Zafarnoma by Sharofiddin Ali Yazdi while he was in Karman. According to the legend, Timur spoke with great interest that he had lost a horse around Nurata and Karmana, and that his soldiers had been looking for the horse for six months, and that these places were woodland and forests.[32,p. 109, 168, 229, 271, 282, 375]

S. Inoyatov and O. Khayitova in her book "Mirror of the History of Karmana" tells about the meeting of Sahibkiran with Javlon-grandfather: Bakhtinur Berdiev, a student of academic lyceum at the Navoi State Pedagogical Institute, meets Kholbuta's grandfather from Ejand village. Kholbaba's grandfather Umarov told about his genealogy and told his great-grandfather, Javlon's great-grandfather, that he had met Sahibkiran.

As the author goes on, we met with Kholbuta's grandfather, went to the cemetery where Javlon was grandfathered, and saw the tomb of his grave. The stone contains some information about the grandfather Javlon. At the same time there are gravestones in the cemetery of the rest of the ancestors of Kholbutta. We received a lot of information from Kholbutta's grandfather. Even today, the name of the village of Ejand is related to the fact that the Sahibkiran was in this place.

Ejand Javlon is the grandfather's grandfather, and after his courage in Amir Temur's army, the village was named after him.

The historical fact of Amir Temur's location on the Great Silk Road, including the historical monuments of the 9th century architectural monastery in Taurus and Karmana in Narshahi's "History of Bukhara", is a historical fact. Historians of the Amir Temur epoch have written that Amir Temur and his eldest son Muhammad Jahongir Mirzo were in the Karmana region.

Sharafuddin Ali Yazdi and Nizamuddin Shomiyah testified in the "Victory" that 
Muhammad Jahongir used the secrets of military skills he learned from his father in the vicinity of Mirzo Karmana, killing 20,000 enemies.[34,p.11, 128, 143]

Mirzo Ulugbek, one of Amir Temur's favorite grandsons, also visited Karmana, Raboti Malik, Nurota, Dabusia Castle. Some paintings reveal that Ulugbek was hunting on the banks of the Zarafshan River, between the Sarmish, Nurata, Aktog and Karakat mountain ranges.

Academician B.Ahmedov writes in his work "Uzbek nation": "The orientalist academician V.Bartold states that in 1460 Amir Nursaidbek, who lived in the village of Nur near Bukhara, attacked Samarkand and Bukhara.[35,p.13] The attempt by Sultan Abusaid to settle the case in vain is futile. Nursaidbek Abusaid's ambassador continued his rebellion and ignored the advice of Khoja Ahror, who had come to the mountain (Nurata Mountains BA). After that, the troops of Samarkand were driven out of the Light and fled into the desert. It is known that when Abusaid marched on Seyistan against Emir Khalil, the emir Nursaidbek was sent by Abusaid to Sultan Hussain Baykar. It was then that he left for Sultan Hussein and did not go to Sabzavor. While Muhammad was in Movarounnahr, Nursaidbek was not far from Shakhruhi and Muhammad joined Joki.

Buriboy Akhmedov quotes this from Masud ibn Usman Kukhistani's "Historical Abulkhair Khan". Historical sources indicate that the fortress of Nur had a great reputation at the time of Nursaidbek's death. Academician B.Ahmedov gives detailed information about him in his works "Uzbek nation", "Mirzo Ulugbek", "Lessons from history".

Nursaidbek Shakhmalik's son is the father of Muhammad Salih, the author of the book "Shayboniynoma". The descendants of Shakhmalik were in great positions in the time of Shahrukh Mirzo. For example, when Shahrukh was appointed son of Mirzo Ulugbek as governor of Samarkand (November 1409), he was appointed by Shakhmok as his father. At that time Ulugbek and Shohmalik appointed Nursaidbek to Nurota.[36,p.111]

Nursaidbek served first to Ulugbek, then to Sultan Abusaid (1415-1469) and later to Muhammad Jouki. This is because the Kingdom has been doing its best in the past. However, he later disrespected Ulugbek and led the state affairs arbitrarily without consulting him. Realizing this, Ulugbek complains about Shohmalik's father Shahrukh Mirzo. Shahrukh then summoned the Kingdom to Herat and gave him a new position. It is for this reason that Nursaidbek will go to Sultan Abusaid, governor of Khurasan. Abusaid appointed him governor of Khorezm (1466-1468). He first served Sultan Abusaid wholeheartedly. For example, Ali Fusari, sent by Abusaid, along with Hassan Sheikh Temur and Said Mazid, Nursaidbek Sultan Hussain expels from Astrabad. Later, Nursaidbek turned away from Abusaid and joined Muhammad Juqi, the grandson of Ulugbek (Abdullatif's son). This is evident from the following: Sultan Abusaid drew troops towards Movaraunnahr. Mohammed Jouki will hold a meeting with the military chiefs in Kofin to discuss the situation and to develop further plans to fight Abu Said. Burqa Sultan, Peshku boys and other Uzbek emirs offer to immediately go to the Amu Darya and block the Abu Said road there. The emirates of Chigatay and Muhammad Jokyi himself agreed. But Amir Nursaidbek, Sultan Argun, and many of the emirates opposed it.[37,p.14-15] They retreat to the right bank of the Syrdarya and propose to hide the fortress of Shahruhiya and to fight Abu Sa'eed again from there. After many discussions, all Chigatay emirs agree with this proposal. The Buka Sultan, the Peshku boys are isolated. Muhammad Jokyi, Nursaidbek and other Chigatay emirs are retreating to Shahruhiya with their soldiers. Furious nomadic Uzbeks, Bukhara and Samarkand loot around and return to Dashti Kipchak.[38,p.111]

In the book "Ulugbek" by B. Ahmedov, in 1463, when Muhammad Jouk and Nursaidbek revolt around Nurata and Shohruhiya, Khoja Ubaydulla Ahror intervened in these conflicts. The fact that he was appointed by Ulugbek and Shakhmalik as the son of such a respected person as far away as Nurata, indicates that Nurata had a great reputation at the time, and Nursaidbek's position.[39,p.10]

Maveraunnahr is a part of the Timurid and Timurid states, and Amir Temur tried to thrive in every way. The establishment of a centralized state in the country, the end of bloody wars, and the establishment of peace have had a profound impact on the economic and cultural life of the people of Movarounnahr, Samarkand and Nurata. In Samarkand Sugd, Zarafshan oasis large water constructions and irrigated agriculture are developed. Nurata people widely and widely used water from the Nurata spring and the Dehbaland springs in irrigated agriculture. Special hydrotechnical facilities: watermelons, bands, lock pools are also widely used in agriculture. During this time, sheep and goats, horses and camels were grazed in the foothills and foothills of Nurata and adjacent to Kyzylkum.

During this period, Nurata's crafts, textiles, pottery, blacksmithing, stone-making, carpet-weaving, felt and mining industries developed.

During Amir Temur's time, bazaars and trade spots were set up in cities, particularly in Nurata. Exchanges and trade relations between the city and farming oasis, nomadic and semi-nomadic population of cattle are expanding.

Local networks of the Great Silk Road penetrated into Nurata oasis through Samarkand, Ishtyhan, Narimon, Korsafar, Kushrabot, Kattakurgan, Mirbazar and Langar. Its Karmana-Karakara-Dehbaland line is focused on Chashmai Nur. The network, which has been separated from Dehbaland, has sprinted into Pashshot through the Bosph. Thus, during the Temurids and Timurids, the local network of the Great Silk Road was directly connected to the central road. Serious steps have been taken to ensure the safety and comfort of trade caravans. To this end, rugs, fortresses, cisterns, bridges and fortifications were built along the caravan roads in small towns and villages of Sogd.

The fortresses of Oktepa, Garasha, Kushrabot, Josh, Nurata, Pashshot, Gazgan and other fortresses along the Nurata oasis are evidence of our opinion. As a result, Sogdian and Nurataan trade and embassy relations with neighboring countries expanded.

During the rule of Timur and Temurids, Samarkand and its subordinated territories were divided into districts. This order was introduced by the Khan of Chigatay Kebek Khan (1318-1326) and continued for centuries[40,p.175]. It is well-known that during the last Temur rulers the state was weakened by the wars. The tribes living in Dashti Kipchik in the north of the country took advantage of this situation and occupied Turkestan in the early 16 th century[41,p.9]

Below are some excerpts from the book "Uzbek ulus" by academician B.Ahmedov, a scholar of the history of Dashti 
Kipchak Uzbeks. In our opinion, they will be of interest to every reader, especially to the residents of Nurata oasis, who are directly involved in these processes. According to Masud ibn Usman Kuhistani, the nomadic Uzbeks include: eagle, apex, bird, chrysanthemum, weed, grapefruit, nettle, jute, chimbay, swallow, kenegas, rabbit, jungle, eagle, Chinese, sluggish, domestic. , district, thousand tribes. In the Sheibaninnoma of the building, there were also tribes and Shulgar among the tribes who used Sheibaniiban in the 1980s. These tribes have different origins, namely, browns, tofu and apothecaries from the Mongols, while the Tututians are of Tibetan origin. The Chinese are the Chinese who lived in northeastern China in the 11th and 12th centuries. According to Fazlullah Ruzbe Khan, at the beginning of the 16th century, the Uzbeks of the Sheiban tribe were Kazakhs and Mangites in Dashti Kipchak.

Muhammad Salih's "Shaybaninnoma" 10,000 troops of Shaybani in 1503: sabshut, apocalyptic, bellwick, eagle, monkey, nman, rabbit, eagle, bird, jaloiir, dwarf, star, nut, tartu, adgu, adlui-son .

Mirhond's book, "The Ruatts of Safo" (The Garden of Pokiza Paradise) reflects the relations of the nomadic Uzbeks with the Temurids. These issues are also covered in the works of Khondamir's Habib us-Siyar (Biographies of Friends) and Mirzo Muhammad Haydar's "History Rashidiy". Masud is the author of the book "History of Abulkhairkhan" in Kokand and many others.

The tribes mentioned above had different areas in the steppe, and their socio-political status. In particular, the eagles owned Tura and its surrounding lands (now Western Siberia) in the 20 s of the 15th century, with their seniors Adabbek and Kepakbek. The mangroves played a major role in the political life of Dashti Kipchak in the late 14th and early 15th centuries. Idukibiy held all power in the Golden Horn between 1396 and 1411 .

Isikek's elder brother Isabek was one of the leaders of Tohtamishkhan (1380-1395), and Fulodkhon served as general commander in 1409-1411. Idiku's grandson was close to Abulkhair Khan. In 1428 Abulkhair Khan was promoted to khanate. Ivory, mangrove, fowl, bird, herbivorous, naiman, chimpanzee, tubay, sliding, jot, chinese-ughur, dwarf, usun, karlaut, domestic, fog, tangut, bell, and about 200 tribal representatives used.

It is natural to ask why the unification of the Dashti Kipchak tribes and the invasion of Maveraunnahr in the oasis of irrigated agriculture. It was caused by a number of socio-economic factors. First of all, it is difficult for ordinary nomads during such a season as the population increase in the steppe, tribal pastures, the struggle for water resources, and the death of many livestock from the regular jute (severe frosts) in Dashti Kipchak. One of the main reasons for the nomadic livestock breeding and farming was jute.[44.p.406] Most of the Dashti Kipchak population, the main farm, required hard work for livestock. The nomads, who fed small cattle, sheep and goats, had to move from pasture to pasture throughout the year, except for 2-3 months in winter. In addition, the nomadic cattle herd had to dig wells, feed in the snow when the snow was thick, feed the animals throughout the year, protect the lambs, cut the wool. In spring and summer, the livestock was grazed on grass-covered pastures, on lakes, on slopes and on steppes. He returned to winter in late autumn. Wintering areas were usually sheltered by wind-storms, bushes and reeds. The most wintering of nomads is on the banks of the Syrdarya River. F Ruzbehan writes that the winters along the Syrdarya coast range up to 300 fars (1800-2000 km), ranging from Turkestan to the Aral Sea. These places have provided people with firewood and livestock rich in nutrients, allowing it to survive the winter better. The nomads also hunted wild animals and birds in the tugai, fishing in rivers and lakes.[45.p.63-64]

Archaeologists excavated settlers from South Kazakhstan, where they found numerous weapons and military equipment. Ruzbehan writes that in the auls of nomads not only military or household items, but also carts and bones of poplars and fibers. Home crafts are common. There are many things that are necessary for the household.

In winter, shortages of fodder caused great difficulties for the settlers, which led them to the invaders. Khan received one-fifth of the spoils. The military booty has also benefited ordinary immigrants. In this regard, the nomadic Uzbeks travel to Khorezm (1431-1435), Samarkand (1451-1461) and other cities and villages of the country.

During the raids, the settlers took away not only goods, livestock and farming products, but also people. Later they were widely used in economic activities or sold as slaves. Thousands of captives were driven away when Abukhair Khan helped Abusaid to conquer Samarkand in 1451.[45,p.68]

According to Nusratnoma, Muhammad Sheibanihon plundered villages in Khojand and Shahrukhia in 1501 when he marched against the ruler of Tashkent, Mahmud Sultan Khan. Sheibani Khan's army captured 200,000 sheep, 5,000 horses, 3,000 slaves and 1,500 captives. According to Ruzbehan and Kokhistani, nomadic Uzbeks were not only captives from other countries but also enslaved captives who were defeated in their internal struggles.

Ruzbe Khan has Uzbeks in three categories: Sheibanids, Kazakhs, Mangites.[47,p.10] The Mangites were the khans of Khojitar Khan (Astrakhan). There have always been wars and conflicts between these three categories. When one wins, the other sells slaves and takes the property and livestock as booty. Only steppe tribes could unite with such talented army chiefs as Abulkhair Khan and Muhammad Sheibani Khan.

Although the village of Nurata has existed since the Neolith, the first information about it can be found in the book "History Bukhara" by Muhammad Narshahi (X century). [48,p.8]. Ancient fortress in the city is a fountain of the Neolithic beneath it, with hundreds and thousands of fishes flowing. In the VII-VIII centuries BC there was a fortress of the Arab Caliphate. Nurata is an ancient and sacred shrine. The spring water was considered sacred. There are many interesting, unusual places in the mountains of Nurata. In the village of Mojirim "Eastern biota" is a tree of 1500-2500 years old, its body is 24 meters, its central king is $12 \mathrm{~m}$. 5-6 people can be located in the lower body of a tree. The locals bind hats around the trees to make sure that their intentions, like the Tibetans and the Japanese, can come true.

According to another legend, Noah's ark came to rest on the top of Mount Life. The story was told by Eversman, a Russian scholar during his 1824 visit to Bukhara, in a book published in Berlin in 1848. In the northeast of the mountain where Nurata and Morguzar meet, locals say that there was a cave on the throne of the throne of Noah, son of Noah. 


\section{RESULT AND CONCLUSION}

This scientific article is called "Feature stories from the history of the Nurata oasis" and it uses the results of ethnographic field studies from 1999 to 2013, archival documents and scientific literature on this topic, as well as historical and ethnographic comparative information on the basis of dissertations and manuals. The article provides interesting information on the indigenous tribes of the Nurata oasis - Oguz-Turkmen, their assimilation over many centuries and their transformation into Uzbek-Turkmen, as well as on other ethnic groups.

\section{REFERENCES}

1. Togaev AR Ethnocultural processes in Nurata oasis (I half of the 20th century) Dissertation. 2011.

2. Mirzaev B, Akhmatkulov K. Pages from Nurata's history. - Tashkent, 1997, p. Internet Information.

3. Sagdullaev A.S. Ancient Uzbekistan is in the earliest written sources. Tashkent, Instructor, 1996

4. Ziyoev A. Karakhanids // Voice of Uzbekistan newspaper. 1994. October 18th.

5. Ergashev Q, Hamidov H. History of Uzbekistan. G. Gulam Publishing House. - Tashkent, 2010.

6. Field ethnographic records of the author. 2013 Angry, Pashshot.

7. Eshov B, Odilov A. History of Uzbekistan. Volume I Tashkent, The New Generation. 2014

8. Field ethnographic records of the author. 2013

9. Eshov B, Odilov A. History of Uzbekistan. Volume I Tashkent, The New Generation. 2014.

10. Shoniyozov K.Sh. The process of formation of the Uzbek people. Tashkent, 2001. The same author. The Kang State and the Gangs. Tashkent, 1990.

11. Askarov A. The history of the Uzbek people. - Tashkent, 2015

12. Kobzeva O.P., Djalilov O.Z. Stranitsy istorii velikogo shelkovogo puti: shelk, spetsii i tea. Tashkent, 2013

13. V Sredney Azii (VI в до н.е. - III в n.е.) Chrestomatiya // POD red. LV Bajenova. - Tashkent, 1940.

14. Shoniyozov K.Sh. The formation of the Uzbek people. - Tashkent, 2001

15. Gulyamov Ya. Nur Bukharsky // Ethnography and Archeology Sredney Azii. -M .., Nauka, 1979.

16. Vamberi A. History of Bukhara or Movaraunnahr. - Tashkent, 1990.

17. Kabirov A. Preferences from Sarmyshsaya. B kn: Istoriya Materialnoy Cultury Uzbekistana. Vyp. 9. Tashkent, 1972.

18. Eshov B.M. Adilov AA History of Uzbekistan, 2014

19. Assoc. From the field notes of A. Kabirov, 2013.

20. Author's field notes Nurata district. Synth q. 1991

21. Gulyamov Ya. G. Nur Bukharsky // Ethnography and Archeology Sredney Azii. -M., 1979. p. 134.

22. Asatov R. Treasury ...

23. Author's Field Information. Nurata district, Pashshot castle. 2013

24. Мақдиси Decscriptio imperimsliemice // BGA: 1877.

25. Muhammad an Narshahi. History of Bukhara. istoriya Bukhara. Tashkent. SMI-Asia, 2011.

26. Muhammadjonov A. History of Uzbekistan. For the 7th grade. Tashkent, "Shark" 2017

27. Ibn al-Asir. Al Kamil Fit History. T. 1. -M., 1973

28. Eshov B, Adilov A. History of Uzbekistan. Tashkent, Eastern, 1999

29. Vamberi H. History of Bukhara or Movarannahr. $-\mathrm{T} .: 1990$.

30. Vamberi H. History of Bukhara or Movarannahr. $-\mathrm{T} .: 1990$.

31. Eshov B, Odilov A. History of Uzbekistan.

32. Sharofiddin Ali Yazdi. Victory Tashkent, 1996

33. Sharofiddin Ali Yazdi. Victory. Tashkent, 1997.

34. Akramov A. "Muhammad Salih". -T, 1996. Nuratoni K.Kh. Do you know your ancestors? Samarkand, 1998.

35. Ahmedov B. The Uzbek nation. Tashkent, 1992

36. Mirzaev B, Akhmatkulov K. Pages from Nurata's history. Tashkent, 1997.

37. Ahmedov B. The Uzbek nation. Tashkent, 1992, 111 p; The same author. History Abulkhairkhaniy is an important source of Uzbek history // Lessons from history. Tashkent, Instructor, 1994.

38. Mirzaev B, Ahmatkulov K. Pages from Nurata's history. Tashkent, 1997
39. Ahmedov B. Central Asia during Genghis Khan and his successors // Lessons from history.

40. Sultanov V. Kochevye plemena Priaralya in XV-XVII vv (Voprosy etnicheskoy and social histories). -M., Nauka, 1982

41. Muhammad Salih. Shaybonniy. Pp. 137-139 bb. // Sultanov T.I. The work shown. $10 \mathrm{p}$

42. Akhmedov B. Nomadic Uzbek State // Lessons from History. 59-104 p

43. Shoniyozov K.Sh. The process of formation of the Uzbek people ..

44. Ahmedov B. The Uzbek nation. Tashkent, 1992, 63-64 p

45. The same work. $68 \mathrm{~b}$.

46. Sultanov T.I. Кочевые plemena Prialya в XV-XVII вв. -M., 1982

47. Markov G.E. Kochevniki Azii. -M., 1976, Jurakulov MJ, Khodzhajov TK Ethnic formation of the population of the Zarafshan oasis. Samarkand, $1980.8 \mathrm{p}$

48. Internet Information. 